\title{
GENETIC ASPECTS OF Sn, Li, Be, Nb-Ta PEGMATITES AND Sn-W VEIN DEPOSITS OF THE DAMARAN OROGENY, NAMIBIA
}

\author{
JUSSI TUOMAS OLLILA
}

OLLILA, JUSSI TUOMAS 1987: Genetic aspects of Sn, Li, Be, Nb-Ta pegmatites and Sn-W vein deposits of the Damaran orogeny, Namibia. Bull. Geol. Soc. Finland 59, Part 1, 21-34.

The pegmatites of the Northern, Central and Southern tin belts of the Damaran orogeny, which contain tin, lithium, beryllium and niobium-tantalum mineralizations, belong to the Abukuma low pressure metamorphic facies series, or to the intermediate-level rare-element pegmatite formations.

The ore deposits of the Goantagab tin belt are cassiterite-wolframite-quartz veins at the closed Brandberg West mine, cassiterite-quartz veins and carbonatequartz-cassiterite veins and orebodies at Goantagab. All the ore deposits of the Goantagab tin belt crosscut the Kuiseb Formation of the Damaran orogeny and are hydrothermal in origin.

According to the present field and fluid inclusion study, the fluid pressure at the time of crystallization of the pegmatites did not exceed $2 \mathrm{~Kb}$ in the Northern, Central and Southern tin belts, considering the phase relations of the lithium minerals (spodumene absent) and the barometry of the fluid inclusions. The depositional pressures increase northwards, however, being about $1 \mathrm{~Kb}$ at Strathmore (Northern tin belt), about $1.5 \mathrm{~Kb}$ at Brandberg West and $2.4 \mathrm{~Kb}$ at Awarab (Goantagab tin belt).

The interaction of metamorphic connate water with hydrothermal fluid of magmatic origin is proposed as the deposition mechanism for vein type cassiterite-wolframite occurrences. The pegmatites may have derived from the residual fraction of volatile-rich Salem granite melts during the waning phases of the Damaran orogeny and crystallized in high water activity zones around their feeder intrusions. The importance of large-scale lineaments in relationship to pegmatites is also indicated.

Key words: tin ores, pegmatite, veins, lineaments, fluid inclusions, $\mathrm{p}-\mathrm{T}$ conditions, genesis, crystallization, Namibia, Damaraland.

Jussi Tuomas Ollila: *25.4.1949-+23.8.1985.

\section{Introduction}

Pegmatites with tin, lithium, beryllium and niobium-tantalum minerals are concentrated in three distinct belts - the Northern, Central and Southern tin belts - in the Damaran orogeny of Namibia (Fig. 1).

Ore deposits in the Goantagab tin belt consist of quartz-carbonate vein systems of hydrothermal origin with variable amounts of 


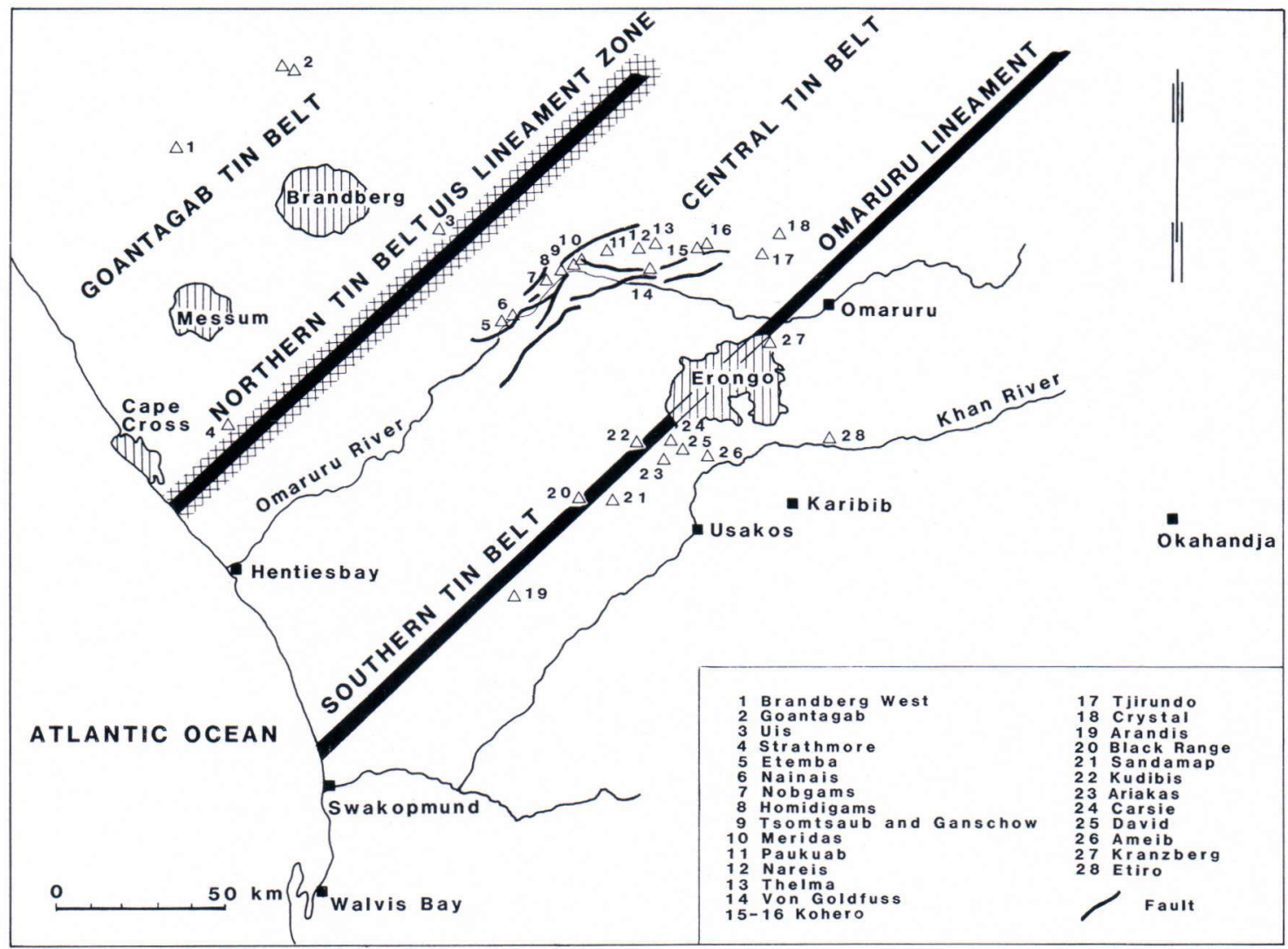

Fig. 1. Localities of the Sn, Li, Be and Nb-Ta pegmatite and other mining sites of the Goantagab, Northern, Central and Southern tin belts of the Damaran orogeny in Namibia.

tin and tungsten. The main deposits are closed Brandberg West mine and various localities in the Goantagab river valley (Fig. 1).

This paper describes a fluid inclusion study carried out on mineral specimens from quartzcassiterite veins from Brandberg West and Awarab (Goantagab) tin (and tungsten) mines, from a petalite-bearing pegmatite at Strathmore in the Northern tin belt, from Davib Ost pegmatite in the Southern tin belt and from Etiro beryllium pegmatite. In addition, the relationship of the tin belts to the major structural lineaments and a model for tin mineralization in the Damara orogenic belt are discussed.

Cassiterite is found in only a few of the pegmatite swarms that lie parallel to the regi- onal northeasterly strike. Beryl is present in large, complex zoned pegmatites, but tin is more or less confined to unzoned pegmatites.

The Damara Orogen, or the Damara metamorphic belt, of Namibia is part of the network of Pan-African orogenic belts surrounding and dissecting Africa. It is made up of a $400 \mathrm{~km}$ wide, intracontinental arm trending northeast between the Congo and Kalahari cratons and a $150 \mathrm{~km}$ wide coastal arm that extends as far north as the Congo and has not been extensively studied. The two arms meet near Swakopmund. The Gariep Orogen forms a southern extension to the coastal arm (Kröner 1977; Martin and Poroda 1977).

Martin (1965) subdivided the intracontinen- 


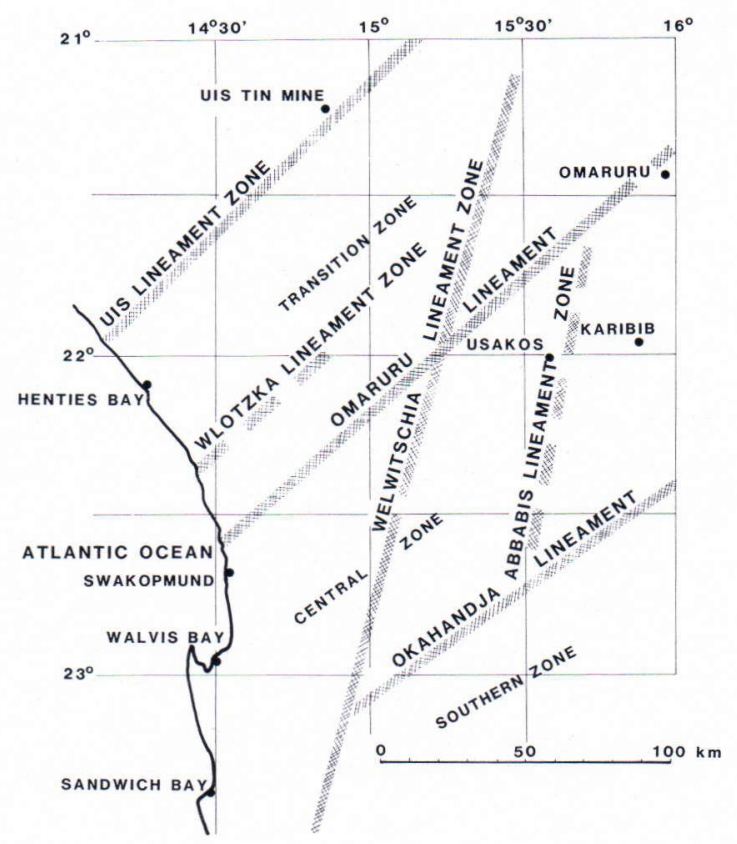

Fig. 2. Schematic representation of interpreted regional structural framework and the main lineaments and lineament zones. Simplified after Corner (1982).

tal branch into a northern miogeosyncline and a southern eugeosyncline, partly separated by the geanticlinal basement called the Kamanjab inlier. Martin and Porada (1977) recognized four main structural domains in the intracontinental branch: a northern platform; a transition zone to the south of the northern platform, where the intensity of folding and metamorphism increase southwards; a central zone, characterized by medium to high grades of metamorphism and voluminous granitic intrusions; and a southern zone (Fig. 2).

More than one pulse metamorphism occurred in the intracontinental branch (Kröner et al. 1978; Sawyer 1978). The metamorphic grade is highest in the central zone and increases along the axis of the orogeny towards the Atlantic coast.

Early metamorphism, with a possible age of 665-634 Ma (Kröner et al. 1978), predated widespread granite intrusion and accompanied the early periods of deformation (Sawyer 1978).
This was followed by another period of metamorphism and by intrusion of various granitic rocks with ages in the order of $550 \mathrm{Ma}$. $\mathrm{Rb} / \mathrm{Sr}$ dating implies an age of about $470 \mathrm{Ma}$ for gneisses of the Khan Formation and the Rössing uranium mine alaskite (Kröner et al. 1978). It is possible that $\mathrm{K} / \mathrm{Ar}$ biotite ages of 520-450 Ma (Haack and Hoffer 1976) also refer to this late- to post-tectonic event.

\section{The Northern tin belt}

In the Northern tin belt, cassiterite-bearing pegmatites occur in a zone up to $25 \mathrm{~km}$ wide that extends about $110 \mathrm{~km}$ from near Cape Cross on the Atlantic coast to the Uis mining area in the northeast. The bulk of the tin mined in Namibia comes from Uis, where opencast mining is carried out in several pits situated within eight major pegmatites, a few of which are up to $1000 \mathrm{~m}$ long and $100 \mathrm{~m}$ wide. The average grade of the pegmatite ore at Uis is 0.13 per cent metallic tin.

The closed petalite mine is situated approximately $23 \mathrm{~km}$ east of Cape Cross and consists of an open pit measuring $150 \mathrm{~m} \times 30-40 \mathrm{~m} \times 20 \mathrm{~m}$ (depth). The wall zones of the pegmatite are up to $1 \mathrm{~m}$ wide and contain coarse books of mica. These zones grade into a core zone consisting of very coarse cleavelandite, abundant petalite and patches of grey quartz. The core zone also contains scattered patches of greisen-like material with cassiterite and tantalite/columbite in a matrix of green muscovite and lumps of grey quartz (5-50 $\mathrm{cm}$ in diameter). The grey quartz is usually surrounded by a narrow $(1-2 \mathrm{~cm})$ zone of feldspars.

Few of the pegmatite bodies in the Cape Cross tin fields have a strike length of more than $100 \mathrm{~m}$. They generally lack zoning and mostly consist of a coarse-grained assemblage of fedspar (both potassium and sodium types), quartz and muscovite. The occurrence of greisen and cleavelandite replacement bodies, with which the cassiterite is usually associated, is 
highly erratic. Minerals locally accompanying the cassiterite are amblygonite, columbitetantalite, beryl and tourmaline.

\section{Central tin belt}

In this belt, extending for $100 \mathrm{~km}$ from Nainais, Damaraland, in the west to Tjirundo 91, Omaruru District, in the east, cassiterite has been recovered from alluvial deposits as well as pegmatites (Haughton et al. 1939; Gevers and Frommurze 1929).

The Omaruru River deposits are confined to the northern bank of the Omaruru River over a distance of more than $32 \mathrm{~km}$ and a width of about $4 \mathrm{~km}$. The country rock consists of schist of the Kuiseb Formation with a pronounced north-east strike.

In the west, the Nainais mining area includes the workings at Nainais, Etemba and Nobgams. The biggest development of pegmatites in the entire tin field is at Etemba and Nainais. Most of the bodies are structurally parallel to the tightly folded schist and are rather poorly mineralized. They attain a maximun width of $6 \mathrm{~m}$ and persist for many huhdreds of metres along strike. The pegmatites cutting across the foliation are generally thinner, albeit frequently richer in tin.

The Homidigams Mine used to be the most important tin mining operation in the Central tin belt. The production of tin concentrate was mainly from a number of individual pegmatite bodies.

The main feature of the Tsomtsaub claims is a persistent pinch-and-swell dyke conformable to the schist and striking northeast over a distance of nearly $3.5 \mathrm{~km}$. Coarse crystals of cassiterite are fairly evenly, though sparsely, distributed in the central and northern parts of the dyke. The cassiterite is finely disseminated in greisen replacement bodies in the southwestern part of the dyke.

In the Meridas area, which measures approximately 400 by $650 \mathrm{~m}$, there are many parallel, lenticular pegmatite dykes and veins, eight of which attain appreciable size. Minaralization is confined to small greisen replacement bodies along the marginal portions of the dykes; the grade is stated to be approximately one per cent tin.

The Paukuab deposit differs from the others in that the cassiterite was recovered from pegmatites situated within granite of the Salem Suite. Alluvial workings, however, accounted for most of the production. The pegmatites follow the directions of jointing in the granite.

The Old Jetske Nareis Thelma and Von Goldfuss claims are situated at Okombahe 112 in Omaruru District. The pegmatites of the Nareis claims are characterized by huge replacement masses of lepidolite-bearing coarse cassiterite and large crystals of coloured lithium tourmaline.

The Von Goldfuss claims lie to the south of Thelma. In these disseminated cassiterite is present in small replacement bodies with lepidolite in quartz-rich pegmatites. It is either deep red or transparent and often occurs as short, tabular, euhedral crystals.

The Kohero tin deposits are situated at Goedehoop 157, Kohero 113 and Kawab 117 (the adjoining farm). In this area the hills of Kuiseb schist are almost completely surrounded by granite of the Salem Suite. Almost all the pegmatites in the schist are more or less cassiteritebearing, the conformable ones showing the highest tin values.

In the Tjirundo-Kompaneno-Okandjou area, cassiterite is found in tourmaline-garnet-bearing pegmatites in crystalline limestone and schist of the Khomas Subgroup as well as in granite of the Salem Suite intruding them.

The Crystal Tin Mine in the northern corner of Kompaneno 104 was the only important producer of cassiterite in the area. Big lumps of cassiterite, weighing up to a hundred kilograms, and pyrrhotite, chalcopyrite, tetrahedrite and pyrite have been extracted from a quartz vein in the main pit. 


\section{Southern tin belt}

The southern tin belt is located in Kuiseb schist and stretches from the Arandis Tin Mine in the west to the Otjimbojo Mine in Swakopmund and Karibib Districts, in the east (Fig. 1). At Onguati 52 the tin belt splits in two, with one arm striking eastwards across Okawayo 46 to Otjimbojo West 47, and the other northeastwards along the southeastern margin of the Erongo Mountain towards Kanona West 84, Omaruru District (Frommurze et al. 1942).

The Sandamap cassiterite pegmatites at Sandamap Noord 115, Damaraland, were the first to be worked for tin in the Karibib area. In the main deposit cassiterite is confined to bodies of lithium-muscovite greisen replacing the huge guartz core of the zoned pegmatite.

Similar pegmatites, though less mineralized, occur to the northwest, northeast and southwest of the main body. On the neighbouring farm, Black Range 72, small quantities of cassiterite occur in muscovite greisen replacement bodies in a tourmaline-rich pegmatite.

The southern tin belt attains its maximum width of almost $5 \mathrm{~km}$ at David Ost 61. Many pegmatites occur within the triangle made up of Kuiseb schist surrounded by Salem and Erongo granites. The stanniferous pegmatites are of the general type, their quartz-feldspar cores being replaced by bodies of muscovite greisen and cleavelandite. Alluvial tin was recovered from many small, dry river beds.

At David Mine (David Ost) cassiterite was recovered from an opencast pit in an elongate greisen replacement body dipping eatwards at a low angle on the footwall side of the pegmatite.

At Carsie Mine (David Ost) the main working is situated in a broad body of pegmatite intruding nonporphyritic granite; cassiterite is limited to linear greisen replacement bodies and quartz-tourmaline fracture fillings.

The Ariakas deposits are situated in the extreme southwest of David Ost 61. Cassiterite occurs throughout the pegmatites principally as disseminated ore. Despite the presence of several shafts and adits recovery seems to have come mainly from eluvial sands and gravels.

Known since 1910, the cassiterite deposits at Ameib 60, Karibib District, were the most extensively developed in the southern tin belt. Activities were concentrated to the north and northwest of the old plant, were an area covering about one square kilometre is cut by numerous dykes of pegmatite.

\section{Goantagab tin belt}

Cassiterite is found in two main types of deposit at various lacalities in the Goantagab river valley in Damaraland, about $40 \mathrm{~km}$ north of Brandberg mountain, viz:

1) In quartz-cassiterite veins that crosscut their host rock, biotite-quartz schist of the Kuiseb Formation. These veins contain variable amounts of sulphides that have completely weathered into iron hydroxides at the old Goantagab and Awarab mining sites, where small-scale open-cut mining has been carried out. At Goantagab mine, the major vein is up to $0.5 \mathrm{~m}$ thick and can be traced for more than half a kilometre along strike. At Awarab, tin has been mined by the local people from shallow-dipping $\left(25^{\circ}\right.$ to $\left.30^{\circ}\right)$ quartz-cassiterite veins between 5 and $25 \mathrm{~cm}$ thick. Cassiterite crystals up to $5 \mathrm{~cm}$ long are found in these veins, which are parallel to the strike and dip of their biotite-quartz schist host.

2) In highly ferruginous, carbonate-rich, tinbearing veins and orebodies emplaced in massive limestone of the Kuiseb Formation. Most of these replacement orebodies are located near the lower contact of the crystalline limestones. The Brandberg West mine is situated about $60 \mathrm{~km}$ inland from the Atlantic coast (Fig. 1). Cassiterite-wolframite mineralization occurs within a swarm of sulphide-deficient quartz veins crosscutting 
their host rock, biotite-quartz schist of the Kuiseb Formation. The quartz-cassiteritewolframite veins vary from a few centimetres to one metre in thickness, forming a network that constitutes a maximun of 12 per cent of the mineralized area located in an anticlinal structure at the closed open pit. In addition to quartz, the main minerals of these veins, are cassiterite, wolframite, ferberite, scheelite, pyrite, tourmaline, fluorite and chalcopyrite.

Cassiterite occurs mainly in the quartz veins themselves but also at their margins with mica and fluorite. The host rock schist may be impregnated with very fine-grained cassiterite, whereas wolframite occurs entirely in the quartz veins.

\section{Tin pegmatites in relation to main fracture zones, i.e. lineaments}

Interpretation of the aeromagnetic data by Corner (1982) has revealed a number of hitherto unrecognized structural lineaments that have an important bearing both on the emplacement of the granites and on the geodynamic processes involved in the formation of the tin belts. Because the relationship of the tin belts to these major structural lineaments or lineament zones has not yet been discussed in the literature, the present paper reviews briefly the relationship between the tin-pegmatites and the lineaments.

A number of structural lineaments and broader lineament zones are evident from the aeromagnetic data, which, apart from the Okahandja lineament, were recognized and named for the first time by Corner (1982). They include the Uis lineament zone, the Omaruru lineament, the Welwitschia lineament zone, and the less prominent Wlotzka and Abbabis lineament zones (Fig. 2).

Computer modelling studies by Corner support the hypothesis that these magnetic linea- ment zones are in fact areas of uplift or geanticlinal ridges bounded by relatively rapid monoclinal downfolding of the stratigraphy.

The Uis lineament zone coincides with the NE-trending Northern tin belt between Cape Cross and Uis tin mine. This lineament zone is demarcated by a linear, regional magnetic low, about $150 \mathrm{~km}$ long and $20 \mathrm{~km}$ wide.

According to Corner (1982), the Omaruru lineament, which coincides with the Southern tin belt (Fig. 1), marks the boundary between the magnetically low domain of the Southern portion of the transition zone and the central zone to the South, constituting a line of monoclinal downfolding of the stratigraphy to the north. Thus, the Omaruru lineament might be a fundamental line of crustal weakness in the tectonic history of the area.

Comparison of LANDSAT satellite colour images with the aeromagnetic colour-composite map of Corner (1982) reveals that:

1) Uis tin mine is located at the intersection of the northwestern portion of the Uis lineament zone (Corner 1982) and a prominent topographic lineament running from SSW to NNE that can be followed on both the aeromagnetic map and satellite photograph from the coastline for at least $40 \mathrm{~km}$ beyond Uis mine;

2) Nainais and the other Omaruru river valley tin pegmatites of the Central tin belt (Etemba, Nobgams, Homidigams, Tsomtsaub, Meridas, Paukuab) are situated in or near a topographic lineament that shows up clearly on the satellite photograph in a roughly SW - NE direction. This lineament, which can also be detected on the aeromagnetic colour-composite maps of Corner (1982), is intersected by two or three narrow lineaments running from SSW to NNE, paralled to the dolerite dykes, visible on the satellite photograph, in the Central tin belt. Two of these lineaments can also be seen on the aeromagnetic map; 
3) Sandamap tin pegmatites of the Southern tin belt are located at the intersection of the Welwitschia lineament zone and Omaruru lineament of Corner (1982). The Welwitschia lineament zone is particularly pronounced on satellite images.

\section{Fluid inclusion study}

\section{Experimental and sample procedures}

Homogenization temperatures were determined using a the most recent type of Chaixmeca combined heating and freezing stage with the heating chamber modified to take doubly polished thick section pieces $10 \mathrm{~mm}$ in diameter. Homogenization temperatures of fluid inclusions that homogenize to a liquid phase were measured twice to avoid including data from leaking inclusions.

The accuracy in the measured temperature range $\left(200^{\circ} \mathrm{C}\right.$ to $\left.450^{\circ} \mathrm{C}\right)$ is better than $\pm 10^{\circ} \mathrm{C}$. At higher temperatures, measurement accuracy is impaired by the optical difficulty of distinguishing between phase boundaries. The accuracy of freezing experiments is $\pm 0.2^{\circ} \mathrm{C}$ in the temperature range $+30^{\circ} \mathrm{C}$ to $-60^{\circ} \mathrm{C}$.

This fluid inclusion study was made using the following mineral specimes:

1) Quartz from a vertical quartz-cassiteritewolframite vein (about $40 \mathrm{~cm}$ wide) in the bottom section of the open pit at the Brandberg West mine;

2) quartz from quartz-cassiterite vein with a shallow dip ( $\left.30^{\circ}\right)$ at Awarab tin mine (Goantagab). The vein is about $10 \mathrm{~cm}$ thick and parallel to the strike and dip of schistosity of the host biotite-quartz schist;

3) quartz from petalite-bearing pegmatite at Strathmore. Grey quartz was collected at the bottom of the open pit from the edge of the largely mined out petalite-rich core;

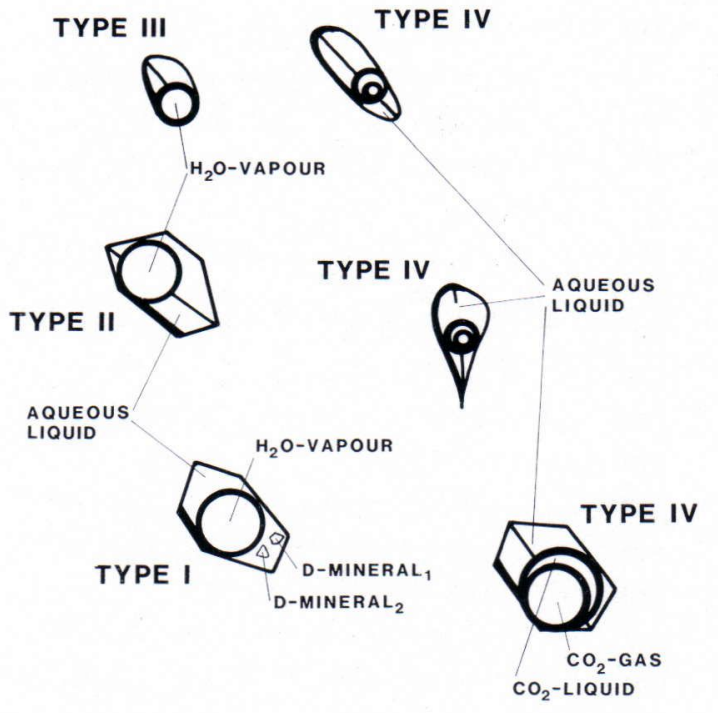

Fig. 3. Different types of primary? fluid inclusions occurring in beryl from the Etiro pegmatite.

4) quartz cut from a large (40 cm long) idiomorphic quartz crystal protruding into an open cavity in the core zone of the main pegmatite body at David Ost; and

5) beryl from the intermediate zone of the main pegmatite body at Etiro (Fig. 3).

\section{Compositional types of fluid inclusions}

Four different compositional types of fluid inclusion were distinguished in the minerals examined. The classification is based on the degree of filling and, for inclusions of types II and III, on the manner of homogenization. For the present purpose, the following classification of inclusions proved to be the most convenient.

Type I Super-saturated inclusions with liquid, vapour and one or two daughter minerals.

Type II Moderate to low salinity inclusions with liquid and vapour phases that can show critical behaviour of homogenization. 
Type III Gas-rich inclusions that contain liquid and vapour phases and homogenize to vapour.

Type IV Complex three- or four-phase inclusions that contain aqueous liquid, liquid $\mathrm{CO}_{2}$ and gaseous $\mathrm{CO}_{2}$.

Type I inclusions tend to be very rare and were encountered in:

1) Brandberg West quartz as apparently primary inclusions that contain one or two specks of unidentified daughter mineral;

2) a few inclusions in beryl from Etiro, having two small unidentified daughter crystals;

3) a few inclusions in quartz from David Ost mine, with halite $(\mathrm{NaCl})$ occurring as the only daughter mineral;

4) inclusions in quartz from Nainais and one Uis pegmatite (Old German workings). Only one or two daughter minerals occur in either locality.

Type II inclusions are the most common in all minerals studied. This type of primary inclusion is most abundant in:

1) quartz of Carsie mine;

2) beryl of Etiro mine; and

3) quartz of Awarab, Brandberg West and Strathmore, where they may occur in equal amounts with Type IV inclusions.

Type II inclusions of primary origin showing critical behaviour of homogenization were encountered in beryl (Etiro) and in quartz from Awarab.

Type III inclusions were usually undersaturated and most common in quartz from Awarab. They were also found in beryl (Etiro), and in Nainais and Uis pegmatite quartz, although in the latter case the homogenization behaviour was not verified by heating.

Type IV inclusions were very abundant in quartz of:

1) Strathmore;

2) Awarab (Goantagab); and

3) Brandberg West. Type IV inclusions were also sometimes found in beryl (Etiro).
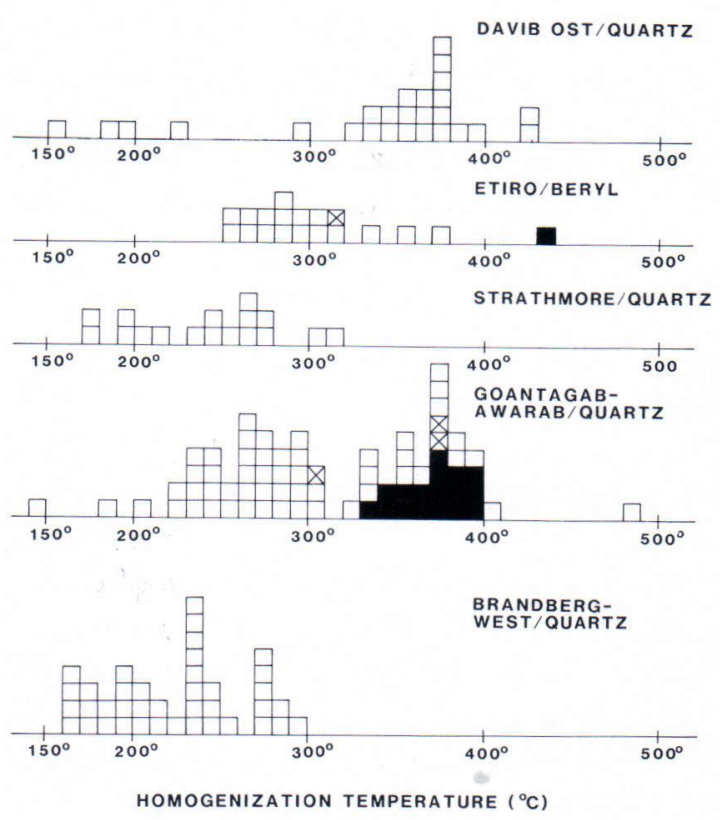

Fig. 4. Frequency distribution of homogenization temperatures of the primary? fluid inclusions. $\square=$ homogenization into liquid phase, $\mathbf{E}=$ homogenization into gas phase, and $\otimes=$ critical behaviour of homogenization.

\section{Homogenization temperatures}

In Fig. 4 the homogenization temperatures measured are presented as histograms for the apparently primary fluid inclusions. Certain trends are evident from these histograms, although too few measurements were made for very reliable major "peaks" or signals to form:

1) Inclusions (Type II) in quartz from David Ost (Fig. 4) form a clear peak at about $370^{\circ} \mathrm{C}$;

2) inclusions (Type II) in beryl (Etiro) seem to be concentrated at an homogenization temperature between $250^{\circ} \mathrm{C}$ and $320^{\circ} \mathrm{C}$;

3) inclusions (Type II) in Strathmore pegmatite quartz have a peak between $190^{\circ} \mathrm{C}$ and $280^{\circ} \mathrm{C}$;

4) inclusions in Awarab quartz have two peaks, one for Type III inclusions at about $370^{\circ} \mathrm{C}$, and another for Type II inclusions between 

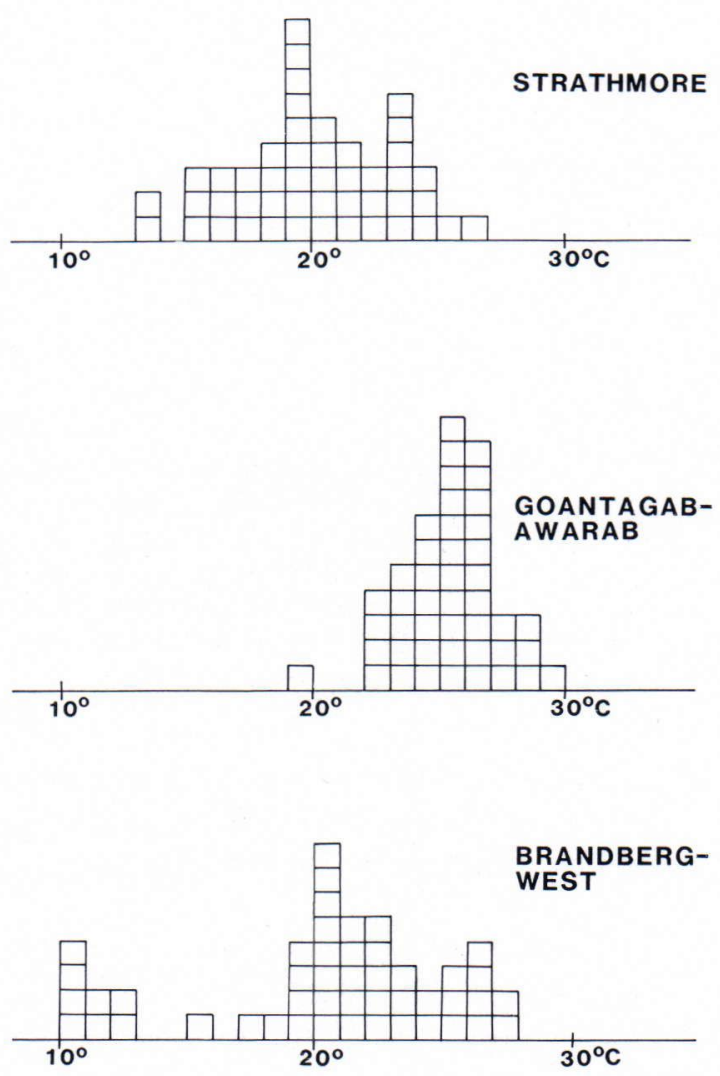

HOMOGENIZATION TEMPERATURE

Fig. 5. Frequency distribution of the homogenisation temperatures between $\mathrm{CO}_{2}+$ gas and $\mathrm{CO}_{2}+$ liquid phases in Type IV primary? fluid inclusions, plotted with $1^{\circ} \mathrm{C}$ interval.

$220^{\circ} \mathrm{C}$ and $310^{\circ} \mathrm{C}$, the estimated "peak" being at about $260^{\circ} \mathrm{C}$;

5) type II inclusions in quartz from Brandberg West show the greatest variation in homogenization temperature, i.e. $160^{\circ} \mathrm{C}$ to $300^{\circ} \mathrm{C}$. Particularly in this case, the number of measurements is too low for a major "peak" or signal to develop. In Fig. 5 the homogenization temperatures of Type IV inclusions are given as frequency distribution histograms.

The average freezing points for Type II inclusions are very low, viz:

1) between $-1^{\circ}$ and $-2^{\circ} \mathrm{C}$ (David Ost);
2) between $0^{\circ}$ to $-10^{\circ} \mathrm{C}$ (Etiro);

3) about $-3^{\circ} \mathrm{C}$ (Strathmore);

4) between $-1^{\circ}$ and $-2^{\circ} \mathrm{C}$ (Awarab); and

5) between $0^{\circ}$ and $-2.5^{\circ} \mathrm{C}$ (Brandberg West).

In terms of salinity given as equivalent weight per cent $\mathrm{NaCl}$ these figures mean, respectively:

$$
\text { wt } \mathrm{NaCl}
$$

1) about 2 to $4 \%$ equiv. (David Ost)
2) about 0 to 15.7
" (Etiro)

3) about 5

(Strathmore)

4) about 2 to $4 \quad$ (Awarab)

5) about 0 to $4 \quad$ (Brandberg West)

\section{Densities of inclusion fluids}

The densities for aqueous and carbon dioxide-rich fluid inclusions were determined from the relevant isochore systems using the above homogenization temperatures and salinities for aqueous inclusions.

The fluid densities for the primary inclusions are as follows:

1) 0.60 for aqueous inclusions (David Ost);

2) 0.60 to 0.65 for aqueous inclusions (Etiro);

3) 0.84 to 0.86 for aqueous inclusions

(Strathmore) and 0.75 to 0.79 for $\mathrm{CO}_{2}$ - rich inclusions (Strathmore); (iv) 0.50 to 0.60 for aqueous inclusions (Awarab) and 0.70 to 0.73 for $\mathrm{CO}_{2}$-rich inclusions (Awarab); and

4) 0.77 to 0.84 for aqueous inclusions (Brandberg West) and 0.70 to 0.85 for $\mathrm{CO}_{2}$-rich inclusions (Brandberg West), main peak 0.77 to 0.78 for $\mathrm{CO}_{2}$-rich inclusions.

\section{Pressures}

The following depositional pressures are obtained from the relevant isochores for $\mathrm{H}_{2} \mathrm{O}$-rich and $\mathrm{CO}_{2}$-rich fluid systems:

1) 0.9 to $1.2 \mathrm{~Kb}$ for Strathmore;

2) $2.4 \mathrm{~Kb}$ for Awarab (main peak);

3) 1.0 to $2.2 \mathrm{~Kb}$ for Brandberg West, the main peak indicating pressure range 1.4 to $1.6 \mathrm{~Kb}$. 


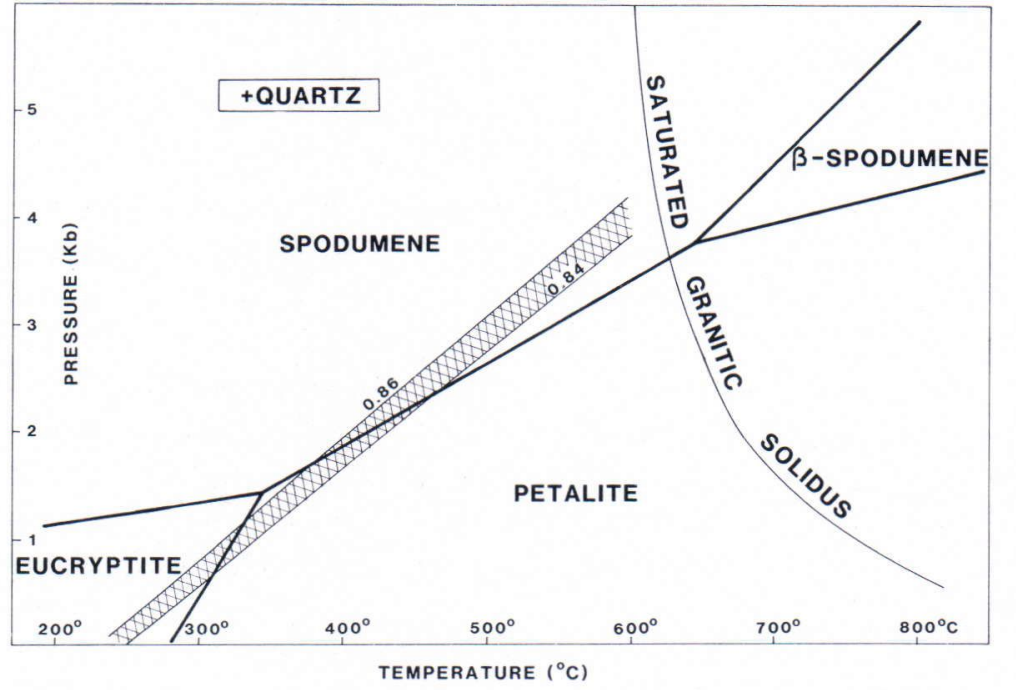

Fig. 6. The system $\mathrm{LiAlSiO}_{4}-\mathrm{SiO}_{2}-$ $\mathrm{H}_{2} \mathrm{O}$ according to the preliminary results of quartz-saturated hydrothermal experiments of London (1981). See text for explanation of the crosshatched isochors in density range $0.84-0.86 \mathrm{gcm}^{-3}$.
On the basis of the phase diagram for the system $\mathrm{LiAl} \mathrm{SiO}_{4}-\mathrm{SiO}_{2}-\mathrm{H}_{2} \mathrm{O}$ (London 1981) and asuming that eucryptite and petalite are coexisting mineral phases at Strathmore, and isochores of $\mathrm{H}_{2} \mathrm{O}$-rich fluid, the inferred pressure would be 0.7 to $1.2 \mathrm{~Kb}$ at Strathmore, which is in very good agreement with the two isochore method (Fig. 6).

\section{Pressure Corections}

Application of the pressure corrections from Potter (1977) to the homogenization temperatures for the $\mathrm{H}_{2} \mathrm{O}$-rich fluid inclusions yields the following true trapping temperatures:

1) the pressure correction would be $105^{\circ} \mathrm{C}$ (at 1 $\mathrm{Kb}$ ) for the main peak at $370^{\circ} \mathrm{C}$, yielding $475^{\circ} \mathrm{C}$ for the true trapping temperature for inclusions in quartz at David Ost;

2) the pressure correction for inclusions in beryl from Etiro would be $90^{\circ}$ to $100^{\circ} \mathrm{C}$ (at 1 $\mathrm{Kb}$ ), yielding a trapping temperature range of $350^{\circ}$ to $450^{\circ} \mathrm{C}$, the main peak being slightly over $400^{\circ} \mathrm{C}$;

3) the pressure correction for inclusions at Strathmore would be $85^{\circ} \mathrm{C}$, indicating trapping temperatures in the range $300^{\circ}$ to $400^{\circ} \mathrm{C}$;
4) main peak at $375^{\circ} \mathrm{C}$ at Awarab needs a pressure correction in excess of $200^{\circ} \mathrm{C}$ at $2.4 \mathrm{~Kb}$, yielding a minimum trapping temperature of $575^{\circ} \mathrm{C}$;

5) at Brandberg West the pressure correction would be $125^{\circ} \mathrm{C}$ to $135^{\circ} \mathrm{C}$ at 1.4 to $1.6 \mathrm{~Kb}$, yielding trapping temperatures in the range $300^{\circ} \mathrm{C}$ to $435^{\circ} \mathrm{C}$.

\section{Occurrence of hydrocarbons}

Fairly abundant hydrocarbons may be present i Type IV $\mathrm{CO}_{2}$-rich inclusions. This was confirmed with freezing measurements. For pure $\mathrm{CO}_{2}$ the melting point is $-56.6^{\circ} \mathrm{C}$; in most cases, however, much lower melting temperatures were measured (Fig. 7). According to the criteria Swanenberg (1979) the other major constituent is $\mathrm{CH}_{4}$ (methane).

\section{Discussion}

\section{Implications of the pressure determinations}

The pressure-temparature conditions for the post-tectonic peak of metamorphism in the 


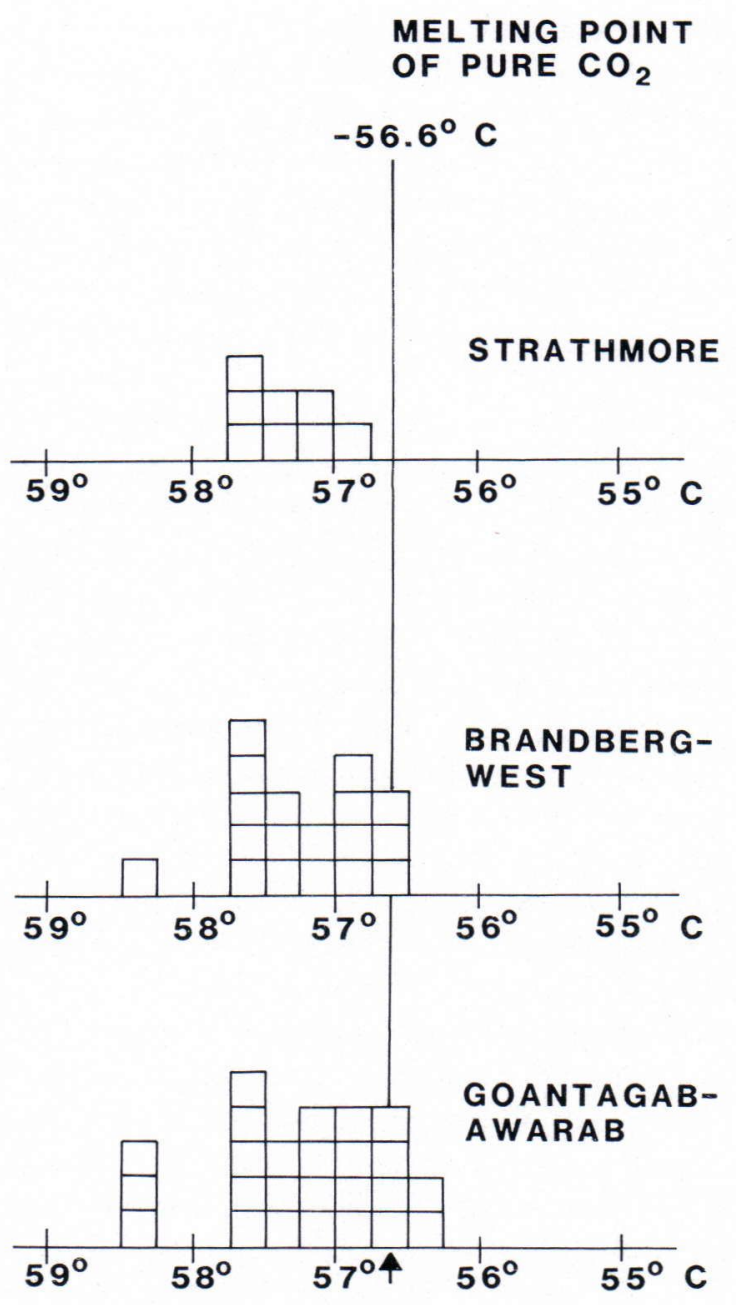

Fig. 7. Melting points of solid carbon dioxides in Type IV fluid inclusions.

Central Zone of the Damaran orogeny (covering the Central and Southern tin belts) are $4.3 \pm$ $0.3 \mathrm{~Kb}$ and $652 \pm 25^{\circ} \mathrm{C}$, as indicated by the 8-phase assemblage garnet + sillimanite $+\mathrm{K}$ feldspar + plagioclase + cordierite + biotite + quartz (+fluid phase). The highest temperatures were calculated (from the pelitic rocks) for the western part of the area.

Generally, the grade of metamorphism increases from the margins of the Damaran orogeny towards its Central Zone. According to the present study, the total pressures for the crystallization of the pegmatites do not exceed $2 \mathrm{~Kb}$ in the Northern, Central and Southern tin belts (in terms of the phase relations of lithium minerals and fluid inclusions). Northwards, however, the pressures increase i.e. being 1.0 $\mathrm{Kb}$ at Strathmore, $1.5 \mathrm{~Kb}$ at Brendberg West and $2.4 \mathrm{~Kb}$ at Awarab (Goantagab). The mode of mineralization in the Goantagab tin belt (cassiterite-wolframite-quartz vein types) coupled with the increasing pressures of deposition implies that northwards the source granitoids of tin (and related rare elements) are located at an increasingly deep level in the earth's crust.

Ginsburg et al. (1979) classified the granitic pegmatites on the basis of geological and petrological criteria, distinguishing four pegmatite formations characterized by different depths of consolidation, mineralizations, and relations to igneous processes and the metamorphic environment. The pegmatites of the Damaran orogeny clearly belong to category II of Ginsburg et al. (1979), which is defined as follows: "Pegmatite formation of intermediate depths (3.5$7.0 \mathrm{~km}$; rare-element pegmatites): pegmatites with $\mathrm{Li}, \mathrm{Rb}, \mathrm{Cs}, \mathrm{Be}$, Ta, (Sn, Nb) mineralization, filling fractures in rocks of Winkler's (1967) cordierite-amphibolite facies, and generated by fractionation of differentiated allochthonous granites" (Cerný 1982, op. cit.).

The pressure of crystallization of the Strathmore petalite pegmatite appears, however, to be slightly lower than that of the pegmatites occurring in the Abukuma low pressure metamorphic facies series of Ginsburg et al. (1979) (Fig. 8). The pressure-temperature diagram of Ginsburg et al. (1979) in Fig. 8 gives the location (but not necessarily the crystallization conditions) of the two pegmatite formations, i.e. Abukuma low-pressure series, and Barrovian intermediate-pressure series, in their metamorphic environmets. 


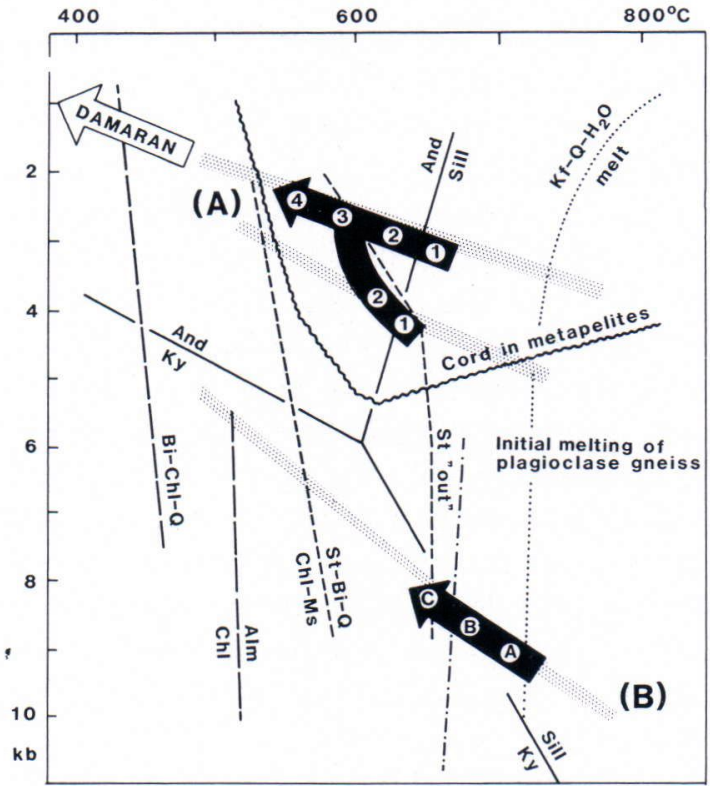

Fig. 8. Pegmatites (black arrows) in metamorphic facies series; stippled bands: (A) - Abukuma low-pressure series. (B) - Barrovian intermediate-pressure series. In intermediate-level rare-element pegmatite formations (in the sense of Ginsburg et al. 1979): 1 = barren, 2 = beryl-bearing, 3 = spodumene-bearing, $4=$ petalite, Ta, Cs-bearing. In deep-level mica-bearing pegmatite formation: $\mathrm{A}=$ barren, $\mathrm{B}=$ muscovite-bearing, $\mathrm{C}=$ beryl-bearing. From Cerný (1982). Location of the tin and lithium-bearing pegmatites (Northern tin belt) of the Damaran orogeny is marked with open arrow "Damaran".

\section{Crystallization of cassiterite-wolframite-quartz deposits}

During their emplacement calc-alkaline magmas exsolve a magmatic fluid phase that may subsequently become involved in ore deposition (Burnham 1967; Holland 1972; Henley and McNabb 1978). Whitney (1975) related the phase chemistry of an isolated crystallizing, granitic system containing three per cent water to the thermal profile of a cooling pluton and derived a model for the evolution of a magmatic vapour phase and for the manner in which the magmatic fluid can transport the ore components to the depositional area. Several models have been suggested in which groundwater convection systems, which operate at hydro- static pressure, can only occur where a fracture system is open to the surface. This in turn is related to the intrinsic strength of the rocks.

Hydraulic fracturing occurs when $\mathrm{P}_{\text {fluid }}>$ $\mathrm{P}_{\text {lithostatic }}+$ tensile strength of rock and is the most likely mechanism whereby magmatic vapour of fluid from deep-level plutons may penetrate upwards to the higher levels of the crust.

Granitoids also appear to favour deep faults or fault zones when they are emplaced to upper levels of the crust at the end of the orogenic cycle. For granite magmas to rise in the crust they must be waterdeficient (Brown and Fyfe 1970). Endogranitic tin deposition can sometimes result from hydration of the granite by host rock aqueous fluids at metamorphic temperatures. Reduction of silicate and primary accessory minerals will also start at this stage, before evolving into deuteric alteration of the granite magma and, finally, as the granite cools and cracks, into hydrothermal convection with flow of formational and then meteoric water through fracture systems (Plant et al. 1983). The deposition mechanism of the cassiterite-wolframite-quartz vein type deposits within the Damaran orogeny is apparently the interaction of a buoyant magmatic fluid with surrounding groundwater of metamorphic origin.

According to this model, ore components derive from a cooling magma column convecting lighter, more volatile components from a deeper level of a crystallizing granitoid up to the deposition sites of the veins. Rare metals enter the system as hydroxyl or chloride (or fluoride) complexes in the magmatic fluid being precipitated in the vein deposits in response to ground-water entrainment, temperature, and wall-rock induced $\mathrm{pH}$ and $\mathrm{fO}_{2}$ variations.

\section{Crystallization of pegmatites}

According to the magmatogenic hypothesis, pegmatites derive from residual volatile-rich granitic melts. The thermogravitational diffu- 
sion model places the source of pegmatites penetrating the outmost "chilled" shell of their parental intrusions and its metamorphic roof in the upper, most fractionated layers of the diffusion column. As far as the immiscibility of the silicate melts in the pegmatite genesis is concerned, immiscibility in fluorine-rich silicate melts operates only at fluorine contents much higher than those attained in most rare-element pegmatites (Cerný 1982).

The present study indicates that the fluid phase present in the inclusions of the pegmatites is mainly a very low-salinity aqueous fluid with variable amounts of carbon dioxide. This may imply that the outer borders of vapour-saturated feeder intrusions of the pegmatites form a zone of high water activity around these bodies. If water were to diffuse into the feeder intrusions from the surrounding rocks, it would have to diffuse not only up a temperature gradient but also through this zone of high water activity. Thus, it seems unlikely that water would diffuse from the country rocks into the partially or wholly molten portions of the feeder intrusions.

Association of muscovite and its lithiumand fluorine-bearing variants with cassiterite is by far the most common feature of the pegmatites in the Kuiseb schists, where lepidolite may be present in great abundance. In 1929 Gevers and Frommurze stated, after their detailed study of the tin-bearing pegmatites of the Southern and Central tin belts, that, "the source of the metalliferous vapours and solutions is the same as the source of the pegmatites in general and that the deposits are connected genetically with the intrusion of the old granite (= Salem suite)... and that cassiterite is a product of pneumatolytic replacement and was derived from ascending metalliferous gaseous solutions". They also point out that, "the cassiterite-muscovite association suggests that the cassiterite was not deposited as the result of a single chemical action. For how is the widespread, almost constant association of cas- siterite and muscovite to be explained on this basis, unless it be supposed that the stannic fluoride was introduced previous to the water vapour necessary for its decomposition".

Thus field evidence strongly suggests that cassiterite was introduced simultaneously with the aqueous fluid phase responsible for the hydration of the feldspars to form orthosilicate muscovite.

This model for mineralization associated with feeder granites requires:

1) a metalliferous granite to rise to a level in the crust at which it creates a thermal anomaly and a magmatic gas "plume" (according to pressure determinations from fluid inclusions an appropriate level would be about $2.7 \mathrm{~km}=1 \mathrm{~Kb}$ ) beneath the surface at the time of pegmatite mineralization, if lithostatic pressure is assumed (at the Northern tin belt);

2) adequate water of suitable chemistry for hydration of primary silicates to occur (thus rocks of low metamorphic grade and pelitic composition will favour mineralization); and

3) a well-developed fracture system. Thus, the mineralization is obviously associated with metalliferous granites in zones that became areas of higt heat flow and fluid circulation during the waning phase of the Damaran orogeny.

\section{Conclusions}

Large-scale lineaments, i.e. well defined linear zones in the earth's crust, may have considerable importance for exploration of Sn, W, $\mathrm{Nb}-\mathrm{Ta}$ and $\mathrm{Li}$ deposits because they indicate the systematic fracture systems that act as channelways along which ore componentcarrying fluids or volatile-rich granitic melts rise from their parent magmas to physico-chemically favourable sites of deposition.

Mineralized zones are erratically distributed both vertically and horizontally because the 
fracture systems themselves are irregular and thus allow groundwater to penetrate to somewhat variable levels in the earth's crust.

The Damaran orogeny is a metallogenic province of apparently multi-cyclic processes of ore formation. Tin and lithium are obviously derived from metasediments and concentrated by secondary enrichment through metamorphism and fractional crystallization into the tin and lithiumferous pegmatites, and also, in the case of tin, into vein-type hydrotheral deposits.

Acknowledgements. The author wishes to thank Dr. Roy Miller and the Geological Survey of Namibia for the opportunity to carry out this investigation, Prof. Oleg von Knorring for his guidance and companionship in the desert, Mr. John Pescha and Mrs. Soili Ahava for their assistance in preparing the drawings, and Miss Kyllikki Hast for typing the manuscript.

\section{References}

Brown, G. C.\& Fyfe, W. S., 1970. The production of granitic melts during ultrametamorphism. Contrib. Mineral. Petrol. 28, 310-318.

Burnham, C. W., 1967. Hydrothermal fluids at the magmatic stage. In Barnes, H. L. (Ed.) Geochemistry of Hydrothermal Ore Deposits. Holt, Rinehart, Winston Inc., New York, pp. 34-76.

Cerný, P., 1982. Anatomy and Classification of Granitic Pegmatites. M.A.C. Short Course Handbook 8, Friesen Printers, Ontario, pp. 1-32.

Corner, B., 1982. An Interpretation of the Aeromagnetic Data Covering a Portion of the Damara Orogenic Belt, with Special Reference to the Occurrence of Uraniferous Granite. Unpubl. Ph.D. Thesis, Univ. Witwaterstrand, Johannesburg, $115 \mathrm{pp}$.

Frommurze, H. F.; Gevers, T. W\& Rossouw, P. J., 1942. The Geology and Mineral Deposits of the Karibib Area, Expl. Sheet 79 (Karibib, S.W.A.), Dept. Min. S. Afr., $180 \mathrm{pp}$.

Gevers, T. W. \& Frommurze H. F., 1929. The tin-bearing pegmatites of the Erongo area, South-West Africa. Trans. Geol. Soc. S. Afr. 32, 111-149.

Ginsburg, A. I.; Timofeyev, I. N. \& Feldman, L. G., 1979. Principles of Geology of the Granitic Pegmatites (in Russian). Nedra, Moscow, 296 pp. As quoted by Cerny (1982) in Anatomy and Classification of Granite Pegmatites. M.A.C. Short Course Handbook 8. Friesen Printers, Ontario.

Haack, U.\& Hoffer, E., 1976. K/Ar ages of biotites from the Damara Orogen, South-West Africa. Trans. Geol. Soc. Afr. 79, 213-216.

Haughton, S. H.; Frommurze, H. F., Gevers, T. W; Schwellnus, C. M., \& Rossouw, P. J., 1939. The Geology and Mineral Deposits of the Omaruru Area, South-West Africa, Expl. Sheet 71 (Omaruru, S. W. A.) Dep. Min. S. Afr., 151 pp.

Henley, R. W. \& McNabb, A., 1978. Magmatic vapour plumes and ground-water interaction in porphyry copper emplacament. Econ. Geol. 73, 1-20.

Holland, H. D., 1972. Granites, solutions, and base metal deposits. Econ. Geol. 67, 281-301.

Kröner, A., 1977. Precambrian mobile belts of southern and eastern Africa - ancient sutures or sites of ensialic mobility? A case for crustal evolution towards plate tectonics. Tectonophysics 40, 101-135.

-; Halpern, M. \& Jacob, R. E., 1978. Rb-Sr geochronology in favour of polymetamorphism in the Pan African Damara Belt of Namibia (South West Africa). Geol. Rundsch. 67, 688-706.

London, $D$., 1981. Preliminary experimental results in the system $\mathrm{LiAlSiO}_{4}-\mathrm{SiO}_{2}-\mathrm{H}_{2} \mathrm{O}$. Carnegie Inst. Washington, Year Book 80, 341-345.

Martin, H., 1965. The Precambrian Geology of SouthWest Africa and Namaqualand. Precambrian Res. Unit, Cape Town, 159 pp.

-; Porada, H., 1977. The intracratonic branch of the Damara Orogen in South West Africa. I Discussion of geodynamic models. Precambrian Res. 5, 311-338.

Plant, J. A.; Watson, J. V.\& Fowler, M. B., 1983. Metalliferous and mineralized Caledonian granites in relation to regional metamorphism and fracture systems in Northern Scotland. Trans. Inst. Min. Met., Sect. B., Appl. Earth Sci. 92, B33-B41.

Potter, R. W., 1977. Pressure corrections for fluid inclusion homogenization temperatures based on the volumetric properties of the system $\mathrm{NaCl}-\mathrm{H}_{2} \mathrm{O}$. U.S. Geol. Surv., J. Res. 5, 603-607.

Sawyer, E.W., 1978. Damaran Structural and Metamorphic Geology of an Area Southeast of Walvis Bay, S. W. Africa/Namibia. Unpubl. M.Sc. Thesis, Univ. Cape Town, 205 pp.

Swanenberg, H. E. C., 1979. Phase equilibria in carbonic systems and their application to freezing studies of fluid inclusions. Contrib. Mineral. Petrol. 68. 303306.

Whitney, J. A., 1975. Vapor generation in a quartz monzonite magna: A synthetic model with application to porphyry copper deposits. Econ. Geol. 70, 346-358.

Manuscript received March 27, 1985 